\title{
THE EFFECTS OF EMOTIONAL LABOR BEHAVIORS ON THE PROJECT TEAM PERFORMANCE
}

\author{
*Mehmet CELIKYAY (Orcih ID: 00000-0003-4243-896X)
}

*Gebze Technical University, Turkey

\begin{abstract}
In the literature of organizational behavior, emotional labor is a very new concept that has been studied since the 1980s. However, when the relevant literature is examined, it is seen that emotional labor is generally studied at the individual level and very few studies are conducted based on project teams.This study aims to research the effects of emotional labor behaviors and top management support determined by the organization that employees must comply with on project team performance. In this study using the Smart (PLS 3.0) method, it was found that other structural antecedents other than discipline had a statistically significant and positive effect on some emotional labor behaviors. In terms of ICT Project teamwork outcomes, it was found that the emotional labor behaviors hadn't any effect on the performance of the project team, but the speed to the market had a statistically significant and positive effect on the market success. Also, top management support was shown to have a moderate role in the relationship between surface behavior and market success.
\end{abstract}

Keywords: Emotional Labor Behaviours, Team Contextual Antecedents, Project Team's Performance, Top Management Support

\section{INTRODUCTION}

All over the world, projects and teams have become a means to enhance organizational performance and competitiveness. The use of project works is a clear trend in businesses and organizations, which makes project management a rapidly developing discipline in modern service societies (Seiler et al, 2012). Teams are one of the most important organizational structures required to achieve business results, which are difficult and complicated to the extent that individuals cannot do on their own and which can only be achieved by a common study of many units (Mansouri, 2014). Especially in the ICT sector, project-based teamwork has become a widely preferred organizational norm. As the use of teams has become a structural norm, it is a necessity to benefit from the abilities of the team members at the highest level within the scope of efforts to improve the performance of these teams and maintain their competitiveness (Günsel, 2008). To develop their competitiveness within the sector in which they operate, businesses need to increase their efficiency by renewing their products, services, and business processes with income-generating business models. Providing the highest level of benefit from the skills of the project team members makes it more important to define the factors that affect team innovation, creativity, and performance.

Behaviors and expressions which team members exhibit to form a team are examined under the concept of "Emotional Labor-(EL)," a specific type of labor that is firstly introduced by Hochschild (1983). In the studies, it is stated that people are a very emotional entity, emotions are the most important sources of individuals, they can be exhibited in the work environment and emotions can be educated (Günsel, 2008). Akgün, Keskin, Byrne, and Günsel (2011) states that social interactions can reveal various emotions, especially in knowledge-intensive projects, while Barczak, Lassk, and Mulki (2010) states that managing these emotions in line with the goals and objectives of the team has significant effects on team outcomes. When the relevant literature, especially from the 1980s to the present day, is examined, it is seen that the emotional behavior efforts that are expected and required from the team members to form an effective team can be expressed under the concept of "Emotional Labor(EL)" (Çelikyay, 2019). Most of the studies on the concept of emotional labor starting with Hochschild (1983) focus on individual outcomes such as job satisfaction, commitment, burnout syndrome, and intention to leave. It is also seen that there is not much work in the related literature about the outcomes of teamwork and the structural antecedents that will enable the team members to make an emotional effort.

Therefore in this study, the organizational structural context first presented by Ghoshal and Barlett (1994) is constructed in three dimensions as discipline, stress, and trust. As such, and the direct effect of emotional 
labor behaviors on team performance is investigated. The fundamental question of this study is whether some emotional labor behaviors determined by the organization that the team members must comply with the project team works in the information and communication technology (ICT) sector have harm on team performance Moving from this, the concept of emotional labor behaviors, which will facilitate the creation and management of effective ICT project teams, have been attempted to present for the first time in literature.

In this study, the organizational context was considered as the antecedent of emotional labor behaviors in project teams,and the role of emotional labor behaviors on the Information and Communication Technology(ICT) project teams performance was researched. Also, in parallel with the studies conducted in Ernst (2002); Akgün, Byrne, Lynn, and Keskin (2007); Grandey (2000) and Cholet, Bryon, Cha, Mother, and Gradual (2012), the effect of top management support on the relationship between emotional labor behaviors and market speed/success was explored. In this respect, this study, it was tried to contribute to the project team works.Besides, research can provide three specific contributions to research on innovation and organization. First, it was untangled those team contextual antecedents and shed some light on their role in emotional labor behaviors. Second, it was delved deeper into emotional labor behaviors, examine it as a three-dimensional second-order concept, and investigated its role as a linking pin between team contextual antecedents and team performance.Third, it was revealed its moderating role of the top management support, in the linkages between emotional labor behaviors and team performance.

*This research derived from "The Effects of Emotional Labor Behaviors on the Project Team Performance" and presented full text at the "(ICLTIBM 2019) 9th International Conference on Leadership, Technology, Innovation, and Business Management: Leadership, Innovation, Media and Communication", 12-13 December 2019, İstanbul, Turkey.

\section{LITERATURE REVIEW}

It is stated that people are a very emotional entity and sometimes individuals' behavior is affected by their emotions, while sometimes individuals can control their emotions (McPhail, 2004).

Besides, thanks to the knowledge of the existing emotions within the organization, it is stated that organizations can exhibit more effective and productive behaviors, since they will deal with fewer problems (Grama and Botone, 2009). As a result, project teams, which are a sub-dimension of organizations are seen as a display area of their feelings towards each other, customers, and internal and external stakeholders. Behaviors and expressions which team members exhibit to form a team are examined under the concept of "Emotional Labor-(EL)," a specific type of labor that is firstly introduced by Hochschild (1983). When organizational behavioral literature is examined, emotional labor behavior is generally associated with emotional exhaustion (Morris and Feldman 1996; Grandey 1999), job satisfaction (Liu, Liu, and Zeng 2011; Duke, Goodman, Treadway, and Breland 2009; Grandey,1999-2000), internalization, organizational commitment, and work tension Liu et al.(2011), business performance Duke et al. (2009), intent to leave work, emotional alienation Grandey $(1999 ; 2000)$, and individual creativity Geng, Liu ,Liu, and Feng (2013). However, existing researches on emotional labor focus more on attitudes and behaviors of employees in the service field Geng et al.(2013) and there are fewer studies which investigating the impact of emotional labor on team-level outputs such as team innovation Liu et al.(2011), team performance Günsel (2014), and team creativity Tierney,Farmer, and Graen (1999).

The fundamental question is that,does the emotional labor behaviors that team members have to comply and that are conditioned by the organization, in project team works in the ICT sector have harm on team performance?. Therefore the effect of emotional labor behaviors which are thought to facilitate the creation and management of effective ICT project teams and shaped by the team structural antecedents, on the team performance, has been tried to be examined. As a result, the following research question is formulated:

RQ: What is the role of team contextual antecedents and emotional labor behaviors in team performance?

The main purpose of this study is to find out how the relationship between team structural antecedents, emotional labor behaviors, and team performance in ICT project teams differs according to the moderator effect of top management support. This research, it is aimed to make three contributions to the literature. First, to discover in the relation between team contextual antecedents and emotional labor behaviors. Second, to find the effects of EL behaviors on team performance, Thirdly, to research the moderating role of top management support in the relation between emotional labor behaviors and team performance. 
Emotional Labor Behaviors

Directing the emotional representation of the employees by the organization management, sometimes can be in written rules or sometimes can be in the form of informal expectations. Employees in business environments often have to consciously or unconsciously manage the presentations of their emotions to behave from them as to expected (Mann, 2006). Emotional Labor (Emotional Labor), which is also referred to as emotional workmanship, is defined as "the display of emotions in the form of facial or physical presentations such as signs and making role, to get a benefit" by Hochschild (1983), who first used this in management literature. Other than Hochschild (1983) definitions as an act of displaying appropriate emotions by Ashforth and Humprey (1993), necessary efforts, planning, and control to express the feelings expected by the organization in interpersonal activities by Morris and Feldman (1996), strengthening, modifying, or suppressing certain emotions to regulate emotional expression by Grandey (2000), and adherence to the emotional representation norms of the organization and their appreciation in the process of emotion and regulation by Liu, Prati, Perrewe, and Ferris (2008) have been introduced. In this study, deep behavior, surface behavior, and automatic emotional regulation dimensions which were used in these four main approaches were used (Çelikyay, 2019).

Deep Behavior is defined as an internal effort that an employee exerts to truly feel the feelings that expect from him by the firm (Hochschild, 1983; Ashforth and Humphrey, 1993). At the same time, It includes the harmony of feelings that one feels and exhibits (Grandey, 1998).

Surface Behavior emerges when there is a significant difference between the emotions that the employee feels and is expected to show from him (Hochschild, 1983; Ashforth and Humphrey, 1993). This dimension of emotional labor is also expressed as an employee's modify verbal, facial and bodies expressions as if he/she was playing a role without changing the feelings that he/she feels.

Automatic Emotional Regulation appears when an employee automatically displays the emotions that the company expects.This dimension is observed when there are very small differences between the real feelings of the employee and the emotional impressions expected from him (Yalçı, 2012). For example, it is said that a nurse may internally sympathize with an injured child patient and may not need to take any role (Zapf, 2002).

\section{HYPOTHESES DEVELOPMENT}

\section{Effective Team Contextual Antecedents and Emotional Labor Behaviors}

Organizational structure is seen as one of the most important elements in the studies on team effectiveness. The organizational structure is defined as the structures or external systems that facilitate or prevents the works that the team has to do in line with its goals. It is stated that organizations need discipline and stress to direct their members in line with organizational goals and targets, and they need support and trust to create a synergistic work environment with cooperation (Ghoshal and Bartlett, 1994; Gibson and Birkinshaw, 2002). In this study, the structural context of teams which is a subset of organizational structure is considered a three-dimensional concept as a discipline, stress, and trust. Top management support which is another dimension, is considered as a moderator in the relationship between emotional labor dimensions and team performance (Peng, 2015; Roxana, 2013; Özbingöl, 2013).

Trust: Trust was described as the opinion that people will act as anticipated and will not be harmful to other people (Barczak et al., 2010). Team trust can also be defined as a collective belief that the project manager or team members are in good faith, that no team member will suffer from the actions of others, and that every member can successfully perform the assigned tasks without any control and monitoring. Trust makes it possible to manage conflicts within the team in an appropriate way and to minimize the negative impacts, thus makes significant contributions to team performance (Akgün et al., 2007b). In such a climate, trust is expected to make it easier for team members to implement the rules of emotional representation expected of them. Therefore,

H1: Trust affects emotional labor behaviors positively and statistically significant.

Team Stress; Team stress can be described as stress that affects members within the framework of terms and conditions (workload, team size,or time pressure) that are generally felt and perceived by team members. It is stated that the sense of urgency of team crisis is related to fear experienced in team anxiety (Akgün et al., 2007b). Although the presence of stress in the work environment positively affects the work 
outcomes up to a certain threshold, it brings negative outcomes such as burnout, taking a dislike to work, intention to leave, and lack of harmony in employees if a certain level of stress is exceeded or can't be managed well (Günsel, 2014). In the process of teamwork, it is stated that to reduce or eliminate the negative effects of stress, team members should make the effort to control their emotions, and participate to emotional labor works without any expectations or pressure arising from their organization and managers(Jarvi, 2015). Thereby;

H2: Team Crises affect emotional labor behaviors positively and statistically significant.

H3: Team Anxiety affects emotional labor behaviors positively and statistically significant.

Discipline; Discipline is expressed as a key element that makes teams a real team as a feature that encourages the voluntary efforts of the members of the organization to meet the standards expected from them (Ghoshal and Bartlett, 1994; Katzenbach and Douglas, 2005). In team discipline studies, it is stated that collective control can cause powerful standards of behavior that result in members' joint values. In case of violation of these common values or norms, it is stated that other members may feel this as a threat to team identity and react more than expected from managers (Fitch and Ravlin, 2004). In general, within the framework of the disciplinary rules determined within the team, it is possible for individuals to have to resort to emotional labor behaviors as they will not be able to express and show their feelings in their natural state or will be restricted. Thereby;

H4: Discipline affects emotional labor behaviors positively and statistically significant.

\section{Team Performance (TP) and Emotional Labor Behaviors}

In the related literature, it is seen that team efficacy is evaluated as an indicator of team success under the name of performance (Akgün, Keskin,and Özdemir, 2004). Market success is defined as the market performance of a new product or service that is released as a result of the project work, while market speed is stated as the duration between the start and submit of the product, service, or project(Dayan and Elianna, 2011; Stanko, Castillo and Aleman, 2012; Aga, 2016). It is stated that success in software projects depends on a natural process requiring knowledge, skill interaction, and intensive social interactions among team members. In this respect, it is stated that the management of the emotions of both the individual and the team members gains importance (Akgün et al., 2011). In this process, it is seen as a necessity for the team members to present their real or sudden emotions as a controlled emotional representation through internal control in communication with each other. Thereby;

H5: Surface behavior affects market speed positively and statistically significant.

H6: Deep behavior affects market speed positively and statistically significant.

H7: Automatic emotional regulation affects market speed positively and statistically significant.

H8: Surface behavior affects market success positively and statistically significant..

H9: Deep behavior affects market success positively and statistically significant.

H10:Auto emotional regulation affects market success positively and statistically significant.

\section{The Relationship Between Market Speed and Market Success}

Both introducing novel products or services before the competitors (market speed) and achieving market success altogether is considered a very challenging process. In the development of new products and services, it is stated that the project teams can present more innovative approaches different from the traditional production process and offer a novel product or service to the market with the compression or support of the top managers (Akgün et al.,2007b). Thereby;

H11: Market speed affects market success positively and statistically significant.

\section{Top Management Support's Moderating Effect}

It is stated that the emotional support provided by a top manager in the project works is a key element in the formation of a common emotion, attitude, comment, and reaction within the team (Hekkala, Newman, Urquhart, and Heiskanen, 2011). In previous research, it was expressed that manager support intensifies the effect of deep behavior on job satisfaction and burnout, and reduces the effect of surface behavior on 
them (Duke et al.2009; Grandey,2000; Chen, Su, Lam, Hu, Huo and Zheng, 2012; Roxana, 2013; Özbingöl, 2013; Peng, 2015). It is also stated that the case of top management support, the sense of crisis, and concern within the team positively affect the speed of learning, presentation to the market and new product success of the team (Akgün et al., 2007b). Thereby;

H12; H13; As top management support increases, the relationship between emotional labor behavior and market speed and market success increases.

\section{RESEARCH METHOD}

\section{Research Model}

Emotional labor is described as a cyclical discrepancy-monitoring and reduction process in which perceptions of emotional displays and display rules are continuously compared. Utilizing control theory as an organizing framework for emotional labor provides a widely accepted theoretical structure for explaining the causal mechanisms involved in the emotional labor process. The control theory is used to describe emotional labor in the broader context of job outputs and explain how positive and negative outcomes can result from the emotional labor process (Diefendorff and Gosserand,2003). Within the scope of this study, based on Edwards (1992) and Diefendorff and Gosserand's(2003)cybernetics or control theoretical model, it was proposed that emotional labor behaviors are related to team performance. The model was developed based on the assumption that emotional labor behaviours in the effective project teams in which have some important team structural antecedents can affect team performance. The model developed in line with the purpose of the research is shown in Figure 1.

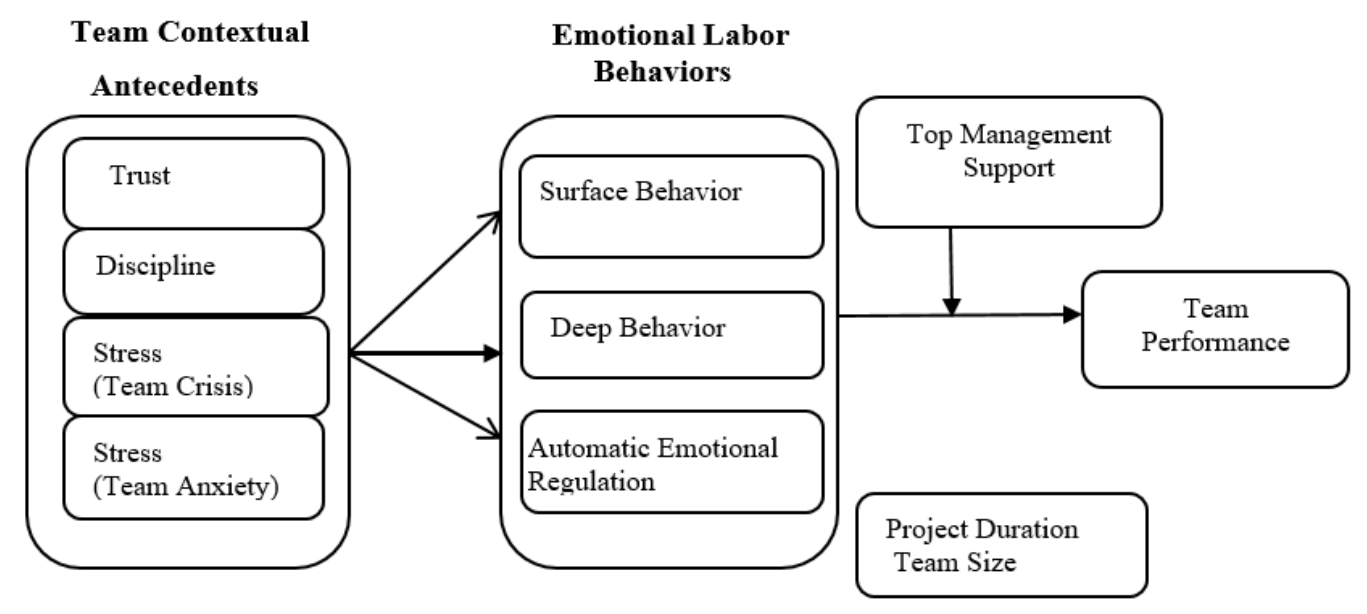

Figure 1: Conceptual Research Model

\section{Sampling Process and Data Collection Method}

This research, according to the 2013-2015 data of The Information and Communication Technologies Authority (ICTA) which has been operating in Turkey, was conducted with 25 private companies, which cover $93 \%$ in terms of market shares in the ICT sector and agreed to respond to the survey. The Survey was conducted with 291 questionnaires from 85 different projects by selecting the convenience sampling technique between May 2016 and January 2017. The questionnaire forms were delivered to the participants by hand or by e-mail. The participants in our study were consist of senior engineers $(32 \%)$, project managers $(5 \%)$, department managers $(5 \%)$, engineers technicians $(44 \%)$, director $(1 \%)$, the owner $(1 \%)$, and other titles $(11 \%)$.

\section{Measures}

The survey was used for the data collection method and consists of two parts. Questions about the demographic information of the participants are included in the first part of the survey. In the second part of the questionnaire, questions related to emotional labor behaviors, team contextual antecedents, top 
management support, and team performance were included. A five-point Likert Type Rating scale ranged from 'strongly agree' (5) to 'strongly disagree' (1) was used throughout the measurement instruments.

Emotional Labor: The questions developed by Brotherdige and Lee (2003) were used for surface behaviors (5 items) and deep behaviors (5 items), which are the sub-dimensions of the emotional labor variance. The questions used in Wong, Ngo, and Wong (2006) and Çekmecelioğlu, Günsel, and Ulutaş (2012) for automatic emotional regulation ( 7 items) were adapted to the team level and included in the questionnaire. The scale has reported alpha reliability of , 88 .

Team Contextual Antecedents: Park and Lee (2014); for trust(6 items), one of the structural antecedent related to effective project teams, Gibson and Birkinshaw (2002); for discipline variable(4 items), Akgün et al (2007); for team stress variable induced by team anxiety and crises(6 items), were adapted to the team level. The scale has reported alpha reliability of, 84 .

Top Management Support: The 5 items developed by Ghoshal and Bartlett (1994) and used by Gibson and Birkinshaw (2002) in the studies were used by adapting to the level of the team to measure the moderator role of top management support. The scale has reported alpha reliability of, 86 .

Team Performance: For market speed and market success 17 items adapted from Akgün, Keskin, Byrne, and Imamoglu (2007)'s works were used. The scale has reported alpha reliability of 0,93. All dimensions were found to be above the acceptable Cronbach $\alpha$ of 0,70 .

Project Duration and Team Size: Project Duration as the logarithmic values of the measurements of passed time in months between the start of the project and the launch to the market of the product or service, and also Team Size as the logarithmic values of the actual number of people involved in project work, were accepted.

\section{ANALYSES AND RESULTS}

Firstly, the items of the scales of the survey were subjected to exploratory factor analysis(EFA)with Statistical Package Program-SPSS 21.0. To test of construct validity of our research model, all variables were tested with factor analysis using principal component analysis with varimax rotation method for determining the factors structure and the results are presented in Table 1. Cronbach $\alpha$ values for measurements were seen to ranged from 0.769 to 0.945 and exceeded the threshold of 0.70 . Furthermore, the Kaiser-Meyer-Olkin test using for the adequacy level of the scales was found between KMO: 0,854 and 0,920 with up from threshold value of 0.70 . Barlett's test $\rho$-sign $(<0.1)$ were also seen to be 0,000 for all variables of our models. After the EFA analysis, it was figured out that confirmatory factor analysis(CFA) can be applied for feasibility of the scale. As shown in Table 1, all normalized pattern loadings were statistically significant $(\mathrm{p}<0.01)$, so convergent validity was proved.

To calculate the reliability of the scale, Chronbach $\alpha$, Composite Reliability (CR), and Average Variance Extracted (AVE) parameters were used. The scale was proved to have internal consistency as the reliability of each measurement was over 0.7 (Brown, 2006; Kline, 2011). Since Cronbach $\alpha$ and CR values seem to exceed the 0.7 threshold value as suggested by Nunnally and Bernstein (1994). As it is demonstrated in Table 1, it was observed that the measurement model maintained sufficient proof for internal consistency. 
Table 1.Factor Analysis Results

\begin{tabular}{|c|c|c|c|c|c|c|c|}
\hline Variables & $\begin{array}{l}\text { Factor } \\
\text { load. }\end{array}$ & $\begin{array}{l}\text { Ind. } \\
\text { Wh. }\end{array}$ & Mean & Std. Dev & Cr. $\alpha$ & $\mathrm{CR}$ & AVE \\
\hline Trust(Team members).. & & & 4,23 & $\mathbf{0 , 7 2}$ & 0,93 & 0,94 & 0,73 \\
\hline $\begin{array}{l}\text { were open and honest when they encountered a problem } \\
\text { during the project. }\end{array}$ & 0,808 & 0,181 & & & & & \\
\hline $\begin{array}{l}\text { helped each other in making a critical decision during the } \\
\text { project }\end{array}$ & 0,89 & 0,195 & & & & & \\
\hline were always willing to help each other during the project. & 0,891 & 0,184 & & & & & \\
\hline were always willing to help each other during the project. & 0,841 & 0,191 & & & & & \\
\hline were completely reliable during the project. & 0,842 & 0,21 & & & & & \\
\hline always felt great confidence in the project. & 0,861 & 0,209 & & & & & \\
\hline Discipline & & & 3,19 & 0,9 & 0,7 & $\mathbf{0 , 8 3}$ & 0,61 \\
\hline $\begin{array}{l}\text { The project team was rewarded or penalized based on a } \\
\text { meticulous measurement of the performance of the project } \\
\text { objectives. }\end{array}$ & 0,811 & 0,532 & & & & & \\
\hline $\begin{array}{l}\text { To improve performance in the project team, the members } \\
\text { were provided with feedback on performance evaluation } \\
\text { results. }\end{array}$ & 0,669 & 0,333 & & & & & \\
\hline $\begin{array}{l}\text { All members of the project team made efforts to } \\
\text { measure/take critical success factors. }\end{array}$ & 0.829 & 0,417 & & & & & \\
\hline Stress (Team Crises)Team Members.. & & & 3,96 & 0,74 & $\mathbf{0 , 8 3}$ & 0,9 & 0,75 \\
\hline $\begin{array}{l}\text { were aware that this project could help in overcoming a } \\
\text { crisis in the company or department. }\end{array}$ & 0,873 & 0,381 & & & & & \\
\hline $\begin{array}{l}\text { were aware that this project could help to reduce the crisis } \\
\text { caused by the environment (competitors, suppliers, and } \\
\text { legal regulations). }\end{array}$ & 0,877 & 0,393 & & & & & \\
\hline $\begin{array}{l}\text { were aware that this project could help solve the crisis } \\
\text { caused by customers and potential users. }\end{array}$ & 0,849 & 0,381 & & & & & \\
\hline Stress (Team Anxiety) The Project Team.. & & & 3,14 & 1,06 & 0,827 & 0,894 & 0,738 \\
\hline $\begin{array}{l}\text { While .. was working on the successful launch of this } \\
\text { project, the company or department chief felt great } \\
\text { pressure. }\end{array}$ & 0,857 & 0,421 & & & & & \\
\hline $\begin{array}{l}\text { thought that if this project failed, their business would be at } \\
\text { risk. }\end{array}$ & 0,852 & 0,468 & & & & & \\
\hline generally felt great pressure to succeed in this project. & 0,868 & 0,277 & & & & & \\
\hline Surface Behaviour(Team Members...) & & & 3,19 & 0,9 & 0,823 & 0,874 & 0,584 \\
\hline $\begin{array}{l}\text { Although ... were distressed and frustrated during the } \\
\text { project, team members were act to strive not to show to } \\
\text { each other. }\end{array}$ & 0,731 & 0,235 & & & & & \\
\hline $\begin{array}{l}\text { tried to exhibit the feelings they should reflect during the } \\
\text { project and the feelings they expected from them even if } \\
\text { they did not match the actual moods }\end{array}$ & 0,711 & 0,29 & & & & & \\
\hline $\begin{array}{l}\text { made an effort not to show what their feeling to each other } \\
\text { in during the project. }\end{array}$ & 0,718 & 0,202 & & & & & \\
\hline $\begin{array}{l}\text { during the project to act in accordance with teamwork to } \\
\text { suppressed their real reactions. }\end{array}$ & 0,826 & 0,257 & & & & & \\
\hline $\begin{array}{l}\text { during the project to act in accordance with team work to } \\
\text { suppressed the their real reactions. }\end{array}$ & 0,834 & 0,318 & & & & & \\
\hline Deep Behaviour(Team Members..) & & & 3,81 & 0,75 & 0,839 & 0,892 & 0,674 \\
\hline
\end{tabular}


tried to evaluate the events during the project from the perspective of other team members.

made a sincere effort to adapt to each other during the project.

\begin{tabular}{|r|r|r|r|r|r|r|}
\hline 0,754 & 0,212 & & & & \\
\hline 0,806 & 0,284 & & & & & \\
\hline 0,832 & 0,293 & & & & & \\
\hline 0,618 & 0,199 & & & & & \\
\hline & & $\mathbf{3 , 9 9}$ & $\mathbf{0 , 5 9}$ & $\mathbf{0 , 8 5}$ & $\mathbf{0 , 8 9}$ & $\mathbf{0 , 5 8}$ \\
\hline
\end{tabular}

Automatic Emotional Regulation(As a Team..)

\begin{tabular}{l}
$0,745 \quad 0,259$ \\
\hline
\end{tabular}

We motivated ourselves during the project as a team.

we checked our rage during the project, discussed the challenges as rational, and surpassed them.

$0,764 \quad 0,232$

Even if we were very angry at each other during the project we were able to calm down quickly and overcome these negative emotions.

we were able to control our emotions well during the project.

we were able to consider with each other's perspective during the project and be respectful.

\begin{tabular}{|r|r|r|r|r|r|r|}
\hline 0,869 & 0,258 & & & & \\
\hline 0,815 & 0,218 & & & & & \\
\hline 0,811 & 0,281 & & & & & \\
\hline & & $\mathbf{4 , 0 4}$ & $\mathbf{0 , 6 5}$ & $\mathbf{0 , 9 2}$ & $\mathbf{0 , 9 4}$ & $\mathbf{0 , 6 5}$ \\
\hline
\end{tabular}

\section{Market Success}

\begin{tabular}{|c|c|c|c|c|c|c|c|}
\hline satisfy volume expectations & 0,817 & 0,197 & & & & & \\
\hline $\begin{array}{l}\text { satisfy other production and commercialization } \\
\text { expectations of the first year. }\end{array}$ & 0,792 & 0,183 & & & & & \\
\hline satisfy sales expectations & 0,884 & 0,201 & & & & & \\
\hline satisfy profit expectations & 0,869 & 0,201 & & & & & \\
\hline satisfy Return on Investment expectations & 0,852 & 0,213 & & & & & \\
\hline satisfy market share expectations & 0,767 & 0,209 & & & & & \\
\hline \multicolumn{8}{|l|}{ Market Speed } \\
\hline was rolled out earlier than our biggest competitor. & 0,781 & 0,324 & & & & & \\
\hline $\begin{array}{l}\text { was rolled out in less time than is normally accepted for } \\
\text { our sector. }\end{array}$ & 0,844 & 0,329 & & & & & \\
\hline $\begin{array}{l}\text { was introduced to the market before or after the original } \\
\text { timetable developed at the beginning of the Project. }\end{array}$ & 0,832 & 0,291 & & & & & \\
\hline $\begin{array}{l}\text { top management was satisfied with the duration from } \\
\text { design to full commercialization }\end{array}$ & 0.769 & 0,295 & & & & & \\
\hline Top Management Support(Our Top Managers...) & & & 3,71 & 0,84 & 0,901 & 0,938 & 0,834 \\
\hline dedicated important effort to developing team members. & 0,718 & 0,194 & & & & & \\
\hline gave all members enough authority to do their jobs well & 0,841 & 0,351 & & & & & \\
\hline push decisions down to the lowest appropriate level & 0,838 & 0,263 & & & & & \\
\hline $\begin{array}{l}\text { rapidly duplicate best practices across organizational } \\
\text { boundaries }\end{array}$ & 0,715 & 0,21 & & & & & \\
\hline gave ready reach to knowledge that others member need. & 0,812 & 0,239 & & & & & \\
\hline \multicolumn{8}{|c|}{$\begin{array}{l}\text { Note: Loadings shown are after oblique rotation and Kaiser normalization.Furthermore, discriminant validity is } \\
\text { supported by two criteria in this study: } \\
\text { The AVE of each latent construct should be higher than the construct's highest squared correlation with any other laten } \\
\text { construct (Fornell and Lacker, 1981). } \\
\text { An indicator's loading should be higher than all of its cross loadings (Hair et. al., 2011). | }\end{array}$} \\
\hline
\end{tabular}


Convergent validity was ascertained by the verification of factor analysis results displayed in Table 1, then each obvious variables were seen to load in relation to the related latent variables.It was seen that Convergent validity is also maintained because the average variance extracted (AVE) was higher than 0.5 (Hair, Anderson, Tatham, and Black,1998). Therefore, the measurements were subjected to CFA in the SEM and it was seen that all the remaining questions were loaded at a value exceeding 0.60 after deduction of 2 questions with a factor load less than 0.60 . Then, the data were subjected to correlation analysis to test the discriminant validity of the measurements. It was seen that the correlation values between the pair of variables are lower than the square root of the AVE value as shown in Table 2. The Cronbach $\alpha$ reliability value of the discipline variable was 0.69. Because Gupta and Somers (1996) suggest that for a relatively newly developed scale, the threshold value can be taken as 0.60 , it was accepted that our metrics meet the criteria of validity and reliability.

Table 2. Correlations among latent variables with sq. rts of AVEs

\begin{tabular}{|c|c|c|c|c|c|c|c|c|c|c|c|c|}
\hline Construct & 1 & 2 & 3 & 4 & 5 & 6 & 7 & 8 & 9 & 10 & 11 & 12 \\
\hline \multicolumn{13}{|l|}{ 1.Trust } \\
\hline 2.Discipline & $0,438 * *$ & & & & & & & & & & & \\
\hline 3.Team Cris. & $0,611^{* *}$ & $0,350 * *$ & & & & & & & & & & \\
\hline 4.Team Anx. & $-0,188$ & $-0,113$ & 0,01 & & & & & & & & & \\
\hline 5.Surface Beh. & 0,002 & 0,076 & $0,273 * *$ & $0,363 * *$ & & & & & & & & \\
\hline 6.Deep Beh. & $0,678^{* *}$ & $0,442 * *$ & $0,650 * *$ & $-0,095$ & $0,230 * *$ & & & & & & & \\
\hline 7.Auto.Em.R. & $0,581 * *$ & $0,373 * *$ & 0,607 & $-0,046$ & $0,290 * *$ & $0,741 * *$ & & & & & & \\
\hline 8. Speed to Market & $0,529 * *$ & $0,337 * *$ & $0,610^{* *}$ & 0,034 & 0,13 & $0,498 * *$ & $0,481 * *$ & & & & & \\
\hline 9. Market Success & $0,294 *$ & 0,055 & $0,479 * *$ & 0,187 & $0,322 * *$ & $0,382 * *$ & $0,380^{* *}$ & $0,599 * *$ & & & & \\
\hline 10.Top Man.Sup. & $0,574 * *$ & $0,534 * *$ & $0,417 * *$ & $0,211^{\text {** }}$ & $-0,038$ & $0,480 * *$ & $0,420 * *$ & $0,358 * *$ & 0,189 & & & \\
\hline 11.Team Size & 0,076 & $-0,021$ & 0,142 & $-0,099$ & & 0,131 & 0,183 & 0,019 & -0 & & & $0,292 *$ \\
\hline 12.Project Duration & $-0,056$ & 0,052 & & & & $-0,096$ & $-0,107$ & $-0,076$ & 0,006 & & & \\
\hline
\end{tabular}

$* \mathrm{p}<.0 .05, * * \mathrm{p}<.0 .01$

Note: Square roots of average variances extracted (AVEs) shown on diagonal

In this study, PLS-Smart 3.0 statistical package program within the Structural Equation Model (SEM) approach, was used to make survey-related measurements and to compute the structural parameters. According to the results obtained using the Smart PLS program, that team structural antecedents in the model explain $16 \%$ of the change in surface behavior $(\mathrm{R} 2=0.16), 54 \%$ of the change in deep behavior and $43 \%$ of the change in automatic emotional regulation. The structural antecedents, control variables and emotional labor behaviors presented in the model explain a $23 \%$ change in-market speed and $41 \%$ change in-market success.

\section{FINDINGS}

According to the results of the hypothesis analyses, it was found that trust has a positive relationship with deep behavior $(\beta: 0,376, \rho<0,001)$, thus $\mathrm{H} 1$ was partly supported. It was seen that there was positive relationship between team crisis and surface behavior $(\beta: 0,352, \rho<0,001)$, deep behavior $(\beta: 0,341, \rho<0,001)$ and Automatic Emotional Regulation $(\beta: 0,352, \rho<0,001)$. Therefore $\mathrm{H} 2$ was supported. But team anxiety was only a positive relationship with the surface behavior $(\beta: 0,331, \rho<0,001)$, therefore $\mathrm{H} 3$ is partly supported. Besides, there wasn't a relationship between discipline and emotional labor behaviors, therefore $\mathrm{H} 4$ is not supported. Interestingly, there were no relationships between emotional labor behaviors and team performance. Therefore, H5, H6, H7, H8, H9, H10 were not supported. However, there was a positive relationship between market speed and market success $(\beta: 0,534, \rho<0,001)$, therefore H11 was supported. Finally, because there was a moderating effect of the top management support between surface behavior and market speed $(\beta: 0,192, \rho<0,1), \mathrm{H} 13$ was partly supported.

\section{CONCLUSION}

As the first antecedent regarding the structural context, trust has a positive and statically significant effect on deep behavior and automatic emotional regulation, which are two of the dimensions of emotional labor. In other words, as trust increases in a teammate, deep behavior and automatic emotional regulation behaviors which exhibited by members also increase (Barczak et al.,2010; Geng et al., 2013; Al-Rais, 
2011). It is understood that the feeling of trust of the project team members towards the other members and the management will make it easier for the members to internalizing the emotions which they don't feel and adopt them as their own. Findings for team stress in this study as the second structural antecedent, in parallel with the studies of Dyne, Jehn and Cummings (2002), Zahavy and Freund(2007), Liu et al.(2008), and Jarvi(2015), team crisis has positive and significant effects on all emotional labor dimensions. Team anxiety, the second sub-dimension of stress, has positive and significant effects only on surface behavior.

One of the interesting results of this study is that, as the third structural antecedent, the discipline involved in this study, unlike Ghoshal and Barlett(1994) and Manz(2009), did not have an affect on emotional labor behaviors. This situation may be to the fact that the need for ICT projects to be conducted according to specific project management processes by its nature and team members have at least an associate degree and have above average cognitive intelligence and competencies, the organization does not need to introduce additional disciplinary rules. Another interesting finding of this study,emotional labor behaviors don't have any clear effect on team performance (market success and the market speed ) in project teams. However, the findings showed that the moderating effect of top management support on the relationship between only surface behavior and market success.

Especially in the ICT sector, it is understood that the launching of new products and services earlier than a competitors contributes to the expected market success of the new product or service. This result is parallel to the results of Akgün et al.(2007b). According to the findings, it is seen that top management support doesn't affect the relationship between emotional labor behaviors and market speed. However, the findings reveal that the relationship between surface behavior and market success increases as top management support increases. It is understood that the relationship between stress and market success which is explained by Collins, Jordan, Lawrence, and Troth(2015);Dyne et al. (2002); Akgün et al.(2007b) provides with team anxiety-surface behavior-market success relationship. In this respect, this finding is in parallel with the related literature.

The generalizability of these results is subject to certain limitations. Firstly, In this study, located in Turkey's ICT sector and the companies operating in Ankara and Istanbul were discussed. For generalizability, it is recommended that the current research model should be tested in different cultural contexts and sectors. Additionally, increasing the sample size would be crucial for the generalizability of the results. This study focuses only on the results of emotional labor behaviors under the influence of some team structural antecedents. Besides, similar studies can be performed with other emotional labor behavior, if any, such as emotional diversity in the literature. Future researchers may evaluate the consequences of emotional labor behaviors that relate to organizational culture, leadership types, and organizational climate. 


\section{REFERENCES}

Aga, D. A. (2016), Factors affecting the success of development projects: A behavioral perspective (No. 867ae95e-d53d-4a68-ad46-62cb80597f4e). Tilburg University, School of Economics and Management.

Akgün, A. E., Keskin, H. and Özdemir, M. (2010), Geçici (Ephemeral) Takımlarda Amacın Açıklığı, Hızlı Bilgi Yayılımı ve Takım Performans Arasındaki iIiş̧kiler. Atatürk Üniversitesi İktisadi ve İdari Bilimler Dergisi, 18(3-4).

Akgün, A. E., Byrne, J. C., Lynn, G. S. and Keskin, H. (2007), Team stressors, management support, and project and process outcomes in new product development projects. Technovation, 27(10), 628-639.

Akgün, A. E., Keskin, H., Byrne, J. and Imamoglu, S. Z. (2007), Antecedents and consequences of team potency in software development projects. Information \& Management, 44(7), 646-656.

Akgün, A. E., Keskin, H., Byrne, J. C. and Gunsel, A. (2011), Antecedents and results of emotional capability in software development project teams. Journal of Product Innovation Management, 28(6), 957973.

Al Rais, M. M. (2011), The Effect of Geographic Dispersion, Language Differences, and Planning Effectiveness on Communication and Project Effectiveness: A Case Study from a Multinational Environment in the UAE (Doctoral dissertation). The British University in Dubai (BUiD)).

Ashfort,B.E.and Humprey,R.H.(1993), Emotional Labor in service roles: the influence of identity, Academy and Management Journal, 18 1993, 88-115.

Barczak, G., Lassk, F. and Mulki, J. (2010), Antecedents of team creativity: An examination of team emotional intelligence, team trust and collaborative culture. Creativity and innovation management, 19(4), 332-345.

Brotheridge, C. M. and Lee, R. T. (2003), Development and validation of the emotional labor scale. Journal of Occupational and Organizational Psychology, 76(3), 365-379.Brown, T. A. (2006). Confirmatory Factor Analysis for Applied Research.Guilford Press, New York

Çekmecelioğlu, H. G., Günsel, A., and Ulutaş, T. (2012), Effects of emotional intelligence on job satisfaction: An empirical study on call center employees. Procedia-Social and Behavioral Sciences, 58, 363-369.

Çelikyay,M.(2019), Duygusal Emek Kavramı,Öncülleri ve Sonuçları:Proje Takımları Üzerinde Bir Araştırma(Doctoral dissertation).Gebze Technical University,Institute of Social Sciences.Doctoral Thesis.https://tez.yok.gov.tr/UlusalTezMerkezi/tezSorguSonucYeni.jsp,Thesis no:54472

Chen, Z., Sun, H., Lam, W., Hu, Q., Huo, Y. and Zhong, J. A. (2012), Chinese hotel employees in the smiling masks: Roles of job satisfaction, burnout, and supervisory support in relationships between emotional labor and performance. The International Journal of Human Resource Management, 23(4), 826845.

Chollet, B., Brion, S., Chauvet, V., Mothe, C. and Géraudel, M. (2012), NPD projects in search of top management support: The role of team leader social capital. M@n@ gement, 15(1), 44-75.

Collins, A. L., Jordan, P. J., Lawrence, S. A. And Troth, A. C. (2016),Positive affective tone and team performance: The moderating role of collective emotional skills. Cognition and Emotion, 30(1), 167-182.

Dayan, M. and Elbanna, S. (2011), Antecedents of team intuition and its impact on the success of new product development projects. Journal of Product Innovation Management, 28(s1), 159-174.

Diefendorff, J. M.and Gosserand, R. H. (2003), Understanding the emotional labor process: A control theory perspective. Journal of Organizational Behavior, 24, 945-959. http://dx.doi.org/10.1002/job.230.

Duke, A. B., Goodman, J. M., Treadway, D. C. and Breland, J. W. (2009), Perceived organizational support as a moderator of emotional labor/outcomes relationships. Journal of Applied Social Psychology, 39(5), 1013-1034.

Dyne, L., Jehn, K. A. and Cummings, A. (2002), Differential effects of strain on two forms of work performance: Individual employee sales and creativity. Journal of Organizational Behavior, 23(1), 57-74. 
Edwards, J. R. (1992), A cybernetic theory of stress, coping, and well-being in organizations. The Academy of Management Review, 17, 238-274.

Ernst, H.(2002),Success factors of new product development: a review of the empirical literature. International Journal of Management Reviews, 4(1), 1-40

Fitch, J. L. and Ravlin, E. C. (2004), Team-based discipline: a theoretical framework. Team Performance Management: An International Journal.

Geng, Z., Liu, C., Liu, X. and Feng, J. (2014), The effects of emotional labor on frontline employee creativity. International Journal of Contemporary Hospitality Management.

Ghoshal, S. and Bartlett, C. A.(1994), Linking organizational context and managerial action: The dimensions of quality of management. Strategic management journal, 15(S2), 91-112.

Gibson, C. B. and Birkinshaw, J. (2002),Contextual determinants of organizational ambidexterity. Centre for Effective Organisations, Marshall School of Business, University of South California, Los Angeles. Retrieved February 2, 2015.

Grama, B. and Boţone, D. (2009), The Role of Emotions In Organizational Behaviour, Annals of the University of Petroşani, Economics, 9(3), 2009, 315-320.

Grandey, A.(1998),Emotional labour. A concept and its correlates.Paper presented at the First Conference on Emotions in Organizational Life, San Diego, CA.

Grandey, A.A.(1999), The Effects of Emotional Labor: Employee Attitudes, Stress, and Performance.(Doctoral Dissertation).Colorado State University, Colorado

Grandey, A. A. (2000), Emotion Regulation in the Workplace: A New Way to Conceptualize Emotional Labor.Journal of Occupational Health Psychology, 5, 2000. 95-110

Gupta, Y. P. and Somers, T. M. (1996), Business strategy, manufacturing flexibility and organizational performance relationships: a path analysis approach. Production and Operations Management, 5(3), 204233

Günsel A.(2008), Yeni Ürün Geliştirme Takımlarında Duygusal Yeteneği Etkileyen Faktörler ve Bunun Proje Performansina Etkileri(Doctoral dissertation). Gebze Institute of Technology, Institute of Social Sciences

Günsel, A. (2014), The Effects Of Emotional Labor On Software Quality: The Moderating Role of Project Complexity. Journal Of Global Strategic Management,16, 2014, December.

Hair, J. F., Black, W. C., Babin, B. J., Anderson, R. E. and Tatham, R. L. (1998), Multivariate data analysis (Vol. 5, No. 3, pp. 207-219). Upper Saddle River, NJ: Prentice hall

Hekkala, R., Newman, M., Urquhart, C. and Heiskanen, A. (2011, January), Emotions in leadership in an IOIS project. In 2011 44th Hawaii International Conference on System Sciences (pp. 1-10). IEEE.

Hochschild, A. R.(1983), The Managed Heart: Commercialization of Human Feeling.Berkeley: University of California Press.

Jarvi, P.A.(2015), Emotion Regulation Methods of Finnish IT Leaders. Faculty of Social Sciences, Norwegian School of Hotel Management.

Katzenbach, J. R. and Smith, D. K. (2005), The discipline of teams. Harvard business review, 83(7), 162.

Kline, R. B.(2011), Principles and Practice of Structural Equation Modeling' 3rd ed. Guilford Press, New York.

Liu, Y., Prati, L. M., Perrewe, P. L. and Ferris, G. R. (2008), The relationship between emotional resources and emotional labor: An exploratory study. Journal of Applied Social Psychology, 38(10), 2410-2439.

Liu, J., Liu, X. and Zeng, X. (2011), Does transactional leadership count for team innovativeness?. Journal of Organizational Change Management.

Mann, S.(2006), Expectations of emotional display in the workplace.Leadership \&Organizational Development Journal, 28(6):552-570. 
Mansouri, M. K. A. (2014). The Effectiveness of Teamwork of National and Expatriate Kg Teachers in Al Ain Schools: A Qualitative Study.

Manz, C. C. (2009), Emotional Discipline: The Power to Choose How You Feel: Easyread Super Large 20pt Edition. ReadHowYouWant. com.

McPhail, K. (2004), An emotional response to the state of accounting education: developing accounting students' emotional intelligence. Critical Perspectives on Accounting, 15(4-5), 629-648.

Morris, J. A. and Feldman, D. C. (1996), The dimensions, antecedents, and consequences of emotional labor. Academy of management review, 21(4), 986-1010.

Nunnally, JC. and Bernstein, IH. (1994), Psychometric Theory, 3rd ed., McGraw-Hill, New York.

Özbingol, B.(2013), Impact of Emotional Labor on Organizational Outcomes: A Comperative Study in Public and Private Universities(Doctoral dissertation). Marmara University Institute of Social Sciences, Department of English Business Management Discipline of Organizational Behaviour

Park, J. G. and Lee, J. (2014), Knowledge sharing in information systems development projects: Explicating the role of dependence and trust. International Journal of Project Management, 32(1), 153-165.

Peng, Y.P. (2015), Buffering the Negative Effects of Surface Acting: The Moderating Role of Supervisor Support in Librarianship.The Journal of Academic Librarianship 41 (2015) 37-46.

Roxana, A.C.(2013), Social Support as a Mediator Between Emotion Work and Job Satisfaction.Procedia - Social and Behavioral Sciences 84 (2013) 601 - 606.

Seiler, S., Lent, B., Pinkowska, M., \& Pinazza, M. (2012). An integrated model of factors influencing project managers' motivation-Findings from a Swiss Survey. International Journal of Project Management, 30(1), 60-72.

Stanko, M. A., Molina-Castillo, F. J. and Munuera-Aleman, J. L. (2012), Speed to market for innovative products: blessing or curse? Journal of Product Innovation Management, 29(5), 751-765.

Tierney, P., Farmer, S. M. and Graen, G. B.(1999), An examination of leadership and employee creativity: The relevance of traits and relationships.Personnel Psychology, 52: 591-620.

Wong, Y. T., Ngo, H. Y. And Wong, C. S. (2006), Perceived organizational justice, trust, and OCB: A study of Chinese workers in joint ventures and state-owned enterprises. Journal of World Business, 41(4), 344-355.

Yalçın, A. (2012), Labor: Dispositional Antecedents and The Role of Affective Events(Doctoral dissertation). Middle East Tech.Ünv.The Graduate School of Social Sciences,Ankara

Zahavy, A. and Freund, A. (2007), Team effectiveness under stress: A structural contingency approach. Journal of Organizational Behavior: The International Journal of Industrial, Occupational and Organizational Psychology and Behavior, 28(4), 423-450.

Zapf, D. (2002), Emotion Work and Psychological Well-Being. A Review of the Literature and Some Conceptual Considerations, Human Resource Management Review 12: 237-68. 